\title{
Medicinal Plants Used in the Treatment and Prevention of Malaria in Cegere Sub- County, Northern Uganda
}

\author{
Godwin Anywar, Charlotte I.E.A. van't Klooster, Robert \\ Byamukama, Merlin Willcox, Patricia A. Nalumansi, Joop de \\ Jong, Protase Rwaburindori, and Bernard T. Kiremire ${ }^{\S}$
}

\section{Research}

\begin{abstract}
In Uganda, malaria has been ranked as a leading cause of morbidity and mortality with Apac District having one of the highest transmission rates. The objective of this study was to assess the use of medicinal plants in preventing and treating malaria and to determine the traditional concept of malaria in Cegere Sub-County, Apac. A snowball sampling method was used to work through a network of informants. Ninety respondents, including traditional healers, were interviewed using focus group discussions and questionnaires. Twenty plant species from 15 families were used for preventing and treating malaria. Most of the plants were herbs (50\%), and leaves (64\%) were the most frequently used parts. Schkuhria pinnata (Lam.) Kuntze ex Thell. was the most frequently cited plant for treating malaria, mentioned by $77 \%$ of the respondents. Traditionally, malaria was known as atipa and was treated ritually. Fewer medicinal plant species were used to treat malaria in Apac compared to other parts of Uganda.
\end{abstract}

\section{Introduction}

Malaria is a life-threatening parasitic disease transmitted by the female Anopheles mosquito (Batista et al. 2009). Although malaria is a preventable and treatable disease, an estimated 247 million cases were reported globally in 2008 causing nearly a million deaths, mostly of children under 5 years, with $80 \%$ of the cases being in Africa (WHO 2013). Malaria is commonly associated with poverty, but it is also a cause of poverty and a major hindrance to economic development (Batista et al. 2009).

As a result of widespread chloroquine and sulphadoxinepyrimethamine resistance, $90 \%$ of sub-Saharan African countries adopted policies of artemisinin-based combination therapy (ACT) for treatment of uncomplicated malaria by 2007 (Frosch et al. 2011). Chloroquine resistance was first documented in Uganda in 1988 (Kamya et al. 2002). Chloroquine and sulfadoxine-pyrimethamine replaced chloroquine as the first-line recommended therapy for uncomplicated malaria in 2002 (Kamya et al. 2002).

Ninety percent of the population in Uganda lives in a high malaria-transmission area, and this creates a heavy burden on the health system (WHO 2013). Malaria in Uganda has been ranked as a leading cause of morbidity and mortality, especially in children under five years (WHO 2008). Uganda has some of the highest recorded malaria transmission rates in Africa, particularly in the areas around Lake Kyoga in Central Uganda (Kiwanuka et al. 2008). The Ministry of Health $(\mathrm{MoH})$ officials in Uganda estimated that each person in Apac District on average re-

\section{Correspondence}

Godwin Anywar, Protase Rwaburindori, Department of Plant Sciences, Microbiology \& Biotechnology" College of Natural Sciences, Makerere University, P.O. Box 7062, Kampala, UGANDA. godwinanywar@gmail.com

Charlotte I.E.A. van't Klooster, Joop de Jong, Amsterdam Institute for Social Science Research (AISSR), University of Amsterdam (UvA), Nieuwe Achtergracht 166, Building B, room B8.01, 1018 WV Amsterdam, THE NETHERLANDS.

Robert Byamukama, Bernard T. Kiremires, Department of Chemistry, Makerere University, P.O. Box 7062, Kampala, UGANDA.

Merlin Willcox, Nuffield Department of Primary Care Health Sciences, University of Oxford, Radcliffe Observatory Quarter, Woodstock Rd., Oxford OX2 6GG, U.K.

Patricia A. Nalumansi, Department of Science \& Technology, International University of East Africa, Kampala, UGANDA.

\$deceased

Ethnobotany Research \& Applications 14:505-516 (2016) 
ceives over 1500 malaria-infected bites every year, which was one of the highest Annual Entomological Inoculation Rates (AEIR) in Africa in 2006 (Okello et al. 2006). Previous estimates have also indicated that at least 12.3 million cases of malaria are registered across Uganda, accounting for $25-40 \%$ of outpatient visits, $20 \%$ of inpatient admissions, $9-14 \%$ of in-patient deaths in health facilities, and $20-23 \%$ of child deaths (MoH 2010).

Historically, communities in tropical regions have used local plants as a means of preventing and treating malaria (Okigbo et al. 2009, Willcox et al. 2004). Over 1200 plant species have been used in treating malaria throughout the world (Willcox et al. 2004). Similarly, medicinal plants are widely used in Uganda to treat malaria (Katuura et al. 2007, Ssegawa \& Kasenene 2007, Tabuti 2008). Some plants which are widely used as anti-malarials have been shown to be significantly active in vitro and or in vivo against Plasmodium species (Willcox et al. 2011). For this reason, herbal medicine continues to play an essential role in covering the basic health needs in many developing countries, including Uganda (Kuglerova et al. 2011).

Many existing antimalarial drugs have been produced from the active compounds of plants such as quinine from the Cinchona bark and artemisinin from Artemisia annua L. (Asteraceae) (Bloland et al. 2000, Willcox et al. 2004). However, the importance of medicinal plants in the treatment of malaria seems to have been neglected by the $\mathrm{MoH}$ in Uganda. In comparison, other African countries like Mali have made advances in incorporating improved traditional medicine (ITM) in the treatment of malaria at the national level (Diallo et al. 2004); Uganda is yet to officially adopt such remedies in treating malaria at the national level. So far, the Uganda Malaria Control Strategic Plans (UMCSP) for 2006 and 2010 remain silent on the role of herbal medicines and medicinal plants in combating malaria (MoH 2006, 2010). There has been an increase in the amount of research documenting the widespread use of medicinal plant species in treatment of malaria in Uganda including work by Katuura et al. (2007), Namukobe et al. (2011), Ssegawa and Kasenene (2007), Stangeland et al. (2011), and Tabuti (2008) among others. It is hoped that such studies can help in generating data that can help inform policy.

Due to the high prevalence and transmission rate of malaria in Apac District, residents must have developed their own conceptualization of malaria including its cause and how it can be prevented and treated. The native people must have adapted to high morbidity and even mortality of malaria by using several coping mechanisms. We hypothesize that the residents must have learned how to use several efficacious medicinal plants to treat malaria. Other coping strategies may have included the use of malaria prevention strategies based on what they believed to cause and spread malaria.
Up until now, no research has been conducted in Apac District to describe the use of medicinal plants in the treatment of malaria and its traditional concept despite the high incidence rate. To fill this knowledge gap, a study was undertaken to assess the use of medicinal plants by the Langi people in treating and preventing malaria problems in Cegere Sub-County, one of sub-counties in Apac District, and to investigate their traditional concept of malaria. It is hoped that the results of this study will contribute to the overall knowledge of medicinal plants in Uganda and might contribute to the development of ITM.

\section{Methods}

\section{Study area}

A survey to identify plants used in the treatment of malaria was conducted in Cegere Sub-County, Apac District (Figure 1). Apac District is located in northern Uganda, north of Lake Kyoga (UDIH 2012), at $2^{\circ} 05^{\prime} 00^{\prime \prime} \mathrm{N}-32^{\circ} 35^{\prime} 00^{\prime \prime} \mathrm{E}$ (NGIA 2015). It borders the districts of Masindi to the west, Lira to the east, Gulu to the north, and Nakasongola to the south (UDIH 2012). Apac District covers a total area of $6541 \mathrm{~km}^{2}$, with $5.4 \%$ of the total area being open water and $4.8 \%$ being permanent or seasonal wetlands (UBOS 2010, UDIH 2012). The vegetation of Apac includes woodlands, grasslands, and thickets, with an average rainfall of 1000-1500 mm per year (UBOS 2010, UDIH 2012). The population of Cegere Sub-County was reported to be 33,358 after the birth and death registration exercise conducted in April 2012 by the Office of the District Statistician.

\section{Data collection}

Data were collected in the months of August and September 2012. The purpose of the study and its objectives were introduced and explained to the district authorities prior to any contact with the local communities. Permission was granted to the research team to carry out the study through the office of the Chief Administrative Officer of Apac District. The study involved both the local people and key informants knowledgeable about medicinal plants. Some of the key informants included traditional healers and traditional birth attendants (TBAs). The average number of households per village was 60 . A total of 90 respondents were interviewed in the three selected villages of Amwak, Aminkech C, and Ongica, in Cegere SubCounty. Prior informed consent was sought from each of the participants before being interviewed. Issues of intellectual property rights were discussed with the respondents. They were informed that should any innovations and or benefits accrue from this study, access to benefit sharing agreements would be made with their input and other stakeholders. 

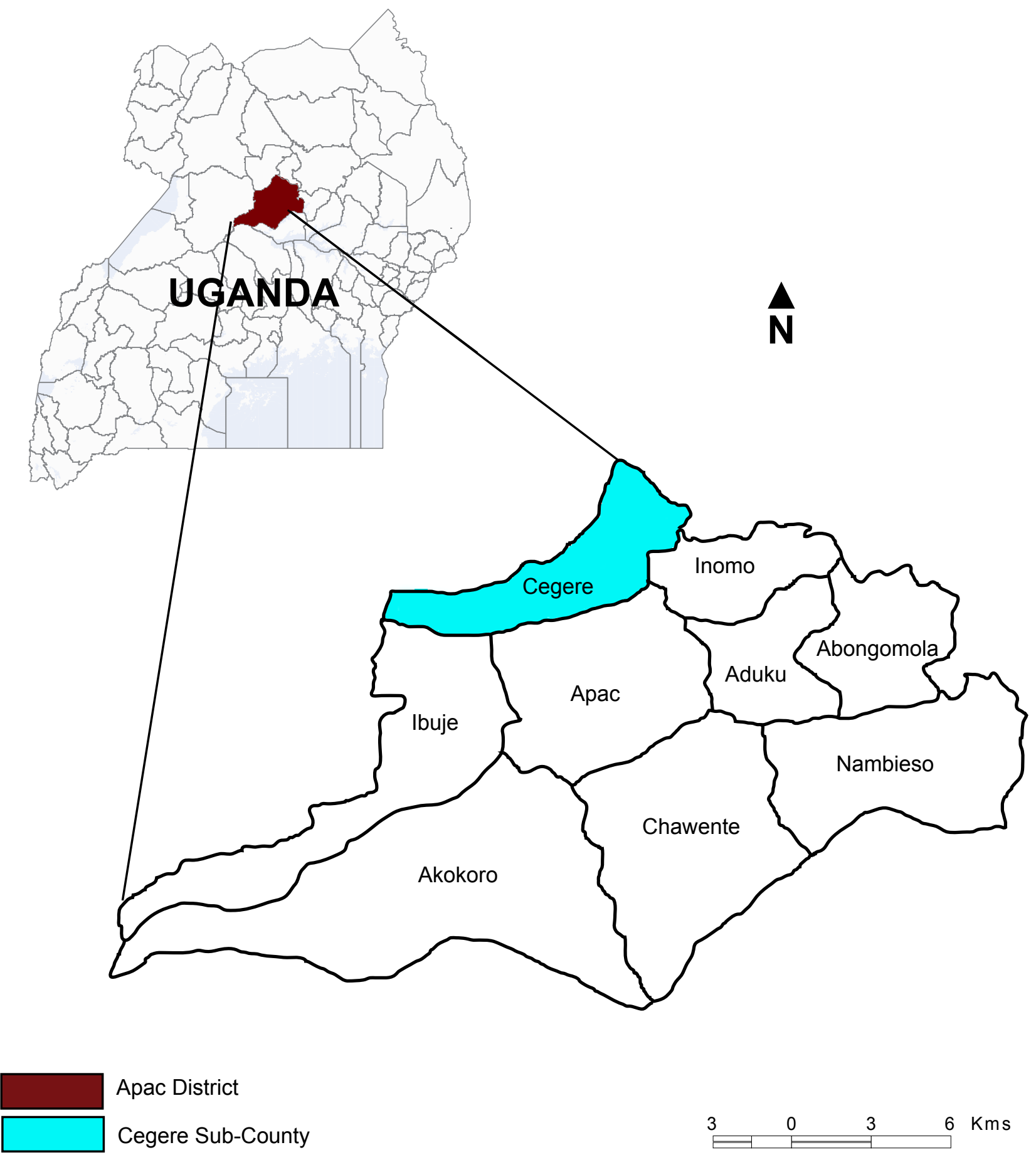

Apac District

Cegere Sub-County

3

0

3

$6 \mathrm{Kms}$

Figure 1. Study area of Cegere Sub-County, Apac District, northern Uganda. 
A set of open-ended, semi-structured questions was addressed to the respondents during the interview sessions. The interviews were conducted by the researchers in the local language (Langi) with the assistance of a local interpreter and a field assistant. The respondents were asked which plant species were used for treating and preventing malaria, which plant parts they used, and methods of preparation and administration as well as information on plant collection areas. The respondents were also asked about their perception of malaria, including how it is spread, how it can be prevented, and how it is treated. One Focus Group Discussion (FGD) was held with 9 herbalists and 2 TBAs as the key informants in the study area. The key informants were recruited through their local traditional healers' association. This was done with the help of the Community Development Officer (CDO) of the sub-county. He contacted the leaders of traditional healers who then mobilized their colleagues to take part in the study. Care was taken to ensure that the number of participants recruited did not exceed twelve as recommended by Heckathorn (2011).

The snowball technique was used to select and interview the traditional healers. The leader of the traditional healers was identified with the help of the CDO. After obtaining his consent, he was interviewed and requested to refer us (the researchers) to another healer within the area. The process was repeated by asking each of the healers interviewed to refer us to other healers whom we also interviewed. This was done to reduce the sampling efforts by quickly identifying key people to interview and to gain access to networks which are usually hard to access by outsiders. After interviewing the healers individually, a FGD was held to include other key informants who were not captured during the snowballing. These included some members of the village health team, who were identified through the office of the CDO. After conducting the FGD, simple random sampling was used to select different community members and households to be interviewed from the selected villages. A reference point was selected from each village, and then the households were selected by moving along a road beginning with the northern direction. The first household along the road was interviewed, and then the next two households were skipped before selecting the fourth household along the same road. This process was repeated along three other roads running east, west, and south from the same reference points in all the selected villages.

\section{Collection of voucher specimens}

The research team was accompanied by selected herbalists and some respondents in the field to help in identifying and collecting the right plant specimens. After confirming the correct identity of the specimen, voucher specimens of each of the plant species mentioned were collected and taken to the Makerere University Herbarium for identification and classification. All the specimens were collected in accordance with standard plant collection procedures described by Martin (1995). Plant presses were used in the field to start drying the samples immediately. The scientific names of plant species were checked and updated with The Plant List (www.theplantlist.org) on 10 June 2014. The plant families were also verified using the Angiosperm Phylogeny Group (AGP) III (www.mobot.org/ MOBOT/research/APweb) on 7 January 2015.

\section{Results}

\section{Social-cultural characteristics}

A total of 90 respondents were interviewed in the three selected villages in Cegere Sub-County. Most (53.3\%) of the respondents interviewed were men. The respondents covered different age groups (Table 1). The majority $(28.9 \%)$ of the respondents were $30-40$ years followed by $19-29$ years (25.6\%). Most of the respondents (97.8\%) were farmers, of whom $13 \%$ were also active as traditional healers. The remaining respondents were teachers and businesswomen.

Medicinal plants were generally easily accessed by the respondents except for some plant species such as Schkuhria pinnata (Lam.) Kuntze ex Thell. which were considered rare. Some of the respondents reported that they often self-medicated whenever they felt they had malaria. This was especially the case when one felt ill and they had no immediate access to healthcare services. If the respondents did not improve after self-medication, they consulted a traditional medical practitioner first. If they still did not improve, they went to a modern health facility for treatment. However, some antimalarial drugs such as quinine tablets were easily accessible at drug shops within the villages. Due to this factor, some people who could afford these drugs also self-medicated. Some of the respondents believed in the efficacy of western medicines but shunned them because of their side effects. Some of the respondents believed in the superiority of their traditional medicines.

Table 1. Age characteristics of the respondents from three villages in Cegere Sub-County, Uganda.

\begin{tabular}{|l|l|l|l|l|l|l|}
\hline Age class (years) & $\mathbf{1 9 - 2 9}$ & $\mathbf{3 0 - 4 0}$ & $\mathbf{4 1 - 5 1}$ & $\mathbf{5 2 - 6 2}$ & $\mathbf{6 3 - 7 3}$ & $\mathbf{7 4 +}$ \\
\hline $\mathbf{N}(\%$ of total) & $23(25.6 \%)$ & $26(28.9 \%)$ & $\mathbf{1 5}(16.7 \%)$ & $8(8.9 \%)$ & $8(8.9 \%)$ & $10(11.0 \%)$ \\
\hline
\end{tabular}




\section{Anywar et al. - Medicinal Plants Used in the Treatment and Prevention of Malaria in Cegere Sub-County, Northern Uganda}

\section{The traditional conceptualization of malaria}

Six of the traditional healers interviewed and five of the elderly respondents reported that malaria used to be locally known as atipa among the Langi. It used to be treated by performing a particular ritual, which involved placing the malaria patient in a rubbish pit and fanning him or her with a winnower. Male patients were fanned thrice while female patients were fanned four times, once a day for one day. This practice was culturally significant and is rooted in the practice of confining a mother to a hut for three days after giving birth to a baby boy or four days if the child is a girl.

After this ritual was performed, the patient would enter a hut and sleep. By the time the patient woke up, it is alleged that they would have recovered from the malaria. Sometimes, the patient would also be made to bathe in water in which the leaves of Hos/undia opposita Vahl (Lamiaceae) had been squeezed. This ritual is no longer carried out because of sensitization of the people on the cause of malaria and the influence of Christianity, which condemned it.

All of the respondents interviewed knew that malaria was caused by mosquito bites. Some of the healers (3) mentioned that one could also catch malaria by staying out in the cold without warm clothing especially early in the mornings or late evenings. Some of the respondents also mentioned that malaria is spread when a mosquito bites an infected person and transfers the malaria to an individual who is not infected. Malaria was described as a disease characterized by headache, high temperature, vomiting, and loss of appetite. Malaria was also reported to be fatal especially once the patient begins vomiting.

\section{Plants used in the prevention and treatment of malaria, mode of preparation, and dosage}

A total of 20 plant species belonging to 15 families were documented as being used for preventing and treating malaria in Cegere Sub-County (Table 2). Out of these,

Table 2. Medicinal plants used for preventing and treating malaria in Cegere sub-County. Citation frequency (CF). Conservation status (CS): cultivated/abundant (CA), cultivated and rare (CR), cultivated/wild and abundant (CWA), wild and abundant (WA), wild and rare (WR), cultivated/wild and rare (CWR). Growth form (GF): herb (H), scrambler (Sc), shrub $(\mathrm{Sh})$, tree $(\mathrm{T})$. Habitat $(\mathrm{H})$ : bush $(\mathrm{B})$; homestead $(\mathrm{H})$, roadside $(\mathrm{R})$, garden $(\mathrm{G})$. Parts used $(\mathrm{PU})$ : leaf $(\mathrm{L})$, fruit $(\mathrm{F})$, root $(\mathrm{R})$, rhizome $(\mathrm{Rh}) .{ }^{*}$ Local name not in Langi language but derive from the common English name adopted by the local people.

\begin{tabular}{|c|c|c|c|c|c|c|}
\hline $\begin{array}{l}\text { Scientific name [family] local } \\
\text { name (Langi), voucher no. }\end{array}$ & CF & CS & GF & $\mathbf{H}$ & PU & Mode of preparation and administration \\
\hline $\begin{array}{l}\text { Schkuhria pinnata (Lam.) Kun- } \\
\text { tze ex Thell. } \\
\text { [Asteraceae] } \\
\text { Chloroquine apure / AG500 }\end{array}$ & 69 & CWR & $\mathrm{H}$ & $\mathrm{B}$ & $\mathrm{L}$ & $\begin{array}{l}\text { Boil fresh leaves, filter \& drink. Children } 1 \times 3 \\
\text { tsp. Adults } 1 \times 3 \text { tbsp. Used singly or mixed } \\
\text { with other herbs e.g., Aloe vera \& Baccha- } \\
\text { roides adoensis Use syrup measurement } \\
\text { cup }(1.2 \mathrm{ml}, 3 \text { times a day for } 2 \text { days). }\end{array}$ \\
\hline $\begin{array}{l}\text { Baccharoides adoensis (Sch. } \\
\text { Bip. ex Walp.) H.Rob. } \\
\text { [Asteraceae] } \\
\text { Okellokello / AG501 }\end{array}$ & 31 & WA & Sh & $\mathrm{B}$ & $\mathrm{L} / \mathrm{R}$ & $\begin{array}{l}\text { Boil fresh leaves, filter \& drink. Children } 1 \times 3 \\
\text { tsp. Adults } 1 \times 3 \text { tbsp. Used singly or mixed } \\
\text { with other herbs e.g., Aloe vera. Use syrup } \\
\text { measurement cup ( } 1.2 \text { ml, } 3 \text { times a day for } \\
2 \text { days). Also leaves are squeezed (a hand- } \\
\text { ful), mixed with water \& used for bathing. }\end{array}$ \\
\hline $\begin{array}{l}\text { Azadirachta indica A.Juss } \\
\text { [Meliaceae] } \\
\text { Neem }^{* *} / \text { AG502 }\end{array}$ & 18 & $\mathrm{CA}$ & $\mathrm{T}$ & $H / G / B$ & $\mathrm{~L}$ & $\begin{array}{l}\text { Boil fresh leaves, filter \& drink. Children } 1 \times 3 \\
\text { tsp. Adults } 1 \times 3 \text { tbsp. Used singly or mixed } \\
\text { with other herbs e.g., Aloe vera. Fresh } \\
\text { leaves chewed for } 3 \text { days } 3 \text { times a day. }\end{array}$ \\
\hline $\begin{array}{l}\text { Crotalaria ochroleuca G.Don } \\
\text { [Fabaceae] } \\
\text { Alayo / AG503 }\end{array}$ & 19 & CWR & $\mathrm{H}$ & $H / G$ & $\mathrm{~L}$ & $\begin{array}{l}\text { Pound fresh leaves, squeeze out the juice } \\
\& \text { drink it. Children } 1 \times 3 \text { tsp. Adults } 1 \times 3 \\
\text { tbsp. Also eaten as sauce. Used for un- } \\
\text { complicated malaria \& as prophylaxis. } \\
\text { Males take it for } 3 \text { days, females for } 4 \\
\text { days. For prophylaxis, leaves cooked with } \\
\text { groundnut paste \& eaten as sauce. }\end{array}$ \\
\hline 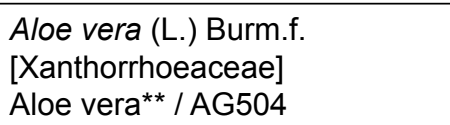 & 13 & CWA & $\mathrm{H}$ & $H / G / B$ & $\mathrm{~L}$ & $\begin{array}{l}\text { Boil fresh leaves, filter \& drink. Children } \\
1 \times 3 \text { tsp. Adults } 1 \times 3 \text { tbsp. Used singly or } \\
\text { mixed with other herbs. }\end{array}$ \\
\hline
\end{tabular}




\begin{tabular}{|c|c|c|c|c|c|c|}
\hline $\begin{array}{l}\text { Scientific name [family] local } \\
\text { name (Langi), voucher no. }\end{array}$ & CF & cs & GF & H & PU & Mode of preparation and administration \\
\hline $\begin{array}{l}\text { Moringa oleifera Lam. } \\
\text { [Moringaceae] } \\
\text { Moringa** / AG505 }\end{array}$ & 8 & $\mathrm{CA}$ & $\mathrm{T}$ & $\mathrm{G} / \mathrm{H}$ & $L / R$ & $\begin{array}{l}\text { Boil handful of fresh leaves in a cup of } \\
\text { water. Drink one glass } 3 \text { times a day for } \\
\text { adults. For children, give } 1 \text { tsp } 3 \text { times a } \\
\text { day. Roots chewed raw or boiled \& drunk } 2 \\
\text { times a day. Pick \& chew handful of fresh } \\
\text { leaves } 2-3 \text { times a day for } 3-4 \text { days. }\end{array}$ \\
\hline $\begin{array}{l}\text { Curcuma longa L. } \\
\text { [Zingiberaceae] } \\
\text { Binjari }^{\star *} \text { / AG506 }\end{array}$ & 7 & CR & $\mathrm{H}$ & $H / G$ & $\mathrm{Rh}$ & $\begin{array}{l}\text { Pick a piece of rhizome, pound it with } 30 \mathrm{ml} \\
\text { water, \& drink twice a day for } 3 \text { days. }\end{array}$ \\
\hline $\begin{array}{l}\text { Senna siamea (Lam.) H.S.Irwin } \\
\text { \& Barneby } \\
\text { [Fabaceae] } \\
\text { Garcia }^{\star *} / \text { AG507 }\end{array}$ & 5 & WA & $\mathrm{T}$ & $\mathrm{B} / \mathrm{G} / \mathrm{H}$ & $\mathrm{R}$ & $\begin{array}{l}\text { Pound fresh roots. Squeeze out juice with } \\
\text { a little water in a cup. Take one cup (about } \\
500 \mathrm{ml} \text { ) once a day for } 3 \text { days. }\end{array}$ \\
\hline $\begin{array}{l}\text { Tithonia diversifolia (Hemsl.) } \\
\text { A.Gray } \\
\text { [Asteraceae] } \\
\text { Akechakech / AG508 }\end{array}$ & 5 & WA & $\mathrm{H}$ & $\mathrm{R} / \mathrm{B}$ & L & $\begin{array}{l}\text { Boil handful of fresh/dry leaves in a cup of } \\
\text { water. Adults drink } 1 \text { glass } 3 \text { times a day. } \\
\text { Children take } 1 \text { tsp } 3 \text { times a day. Take for } \\
4 \text { days. Can be mixed with other herbs e.g., } \\
\text { Baccharoides adoensis \& Schkuhria pinnata. }\end{array}$ \\
\hline $\begin{array}{l}\text { Ocimum forsskaolii Benth. } \\
\text { [Lamiaceae] } \\
\text { Yat cola / AG509 }\end{array}$ & 5 & WA & $\mathrm{H}$ & $\mathrm{B} / \mathrm{G} / \mathrm{H}$ & L & $\begin{array}{l}\text { Squeeze handful of fresh/dry leaves in } \\
\text { warm water \& use for bathing patient } \\
\text { once a day to manage fever. Leaves are } \\
\text { sun dried \& burnt in the house to produce } \\
\text { smoke to repel mosquitoes. }\end{array}$ \\
\hline $\begin{array}{l}\text { Manihot esculenta Crantz } \\
\text { [Euphorbiaceae] } \\
\text { Mogo / AG515 }\end{array}$ & 5 & CA & $\mathrm{H}$ & G & $\mathrm{F}$ & $\begin{array}{l}\text { Peelings are sun dried \& burnt in the house } \\
\text { to produce smoke to repel mosquitoes. }\end{array}$ \\
\hline $\begin{array}{l}\text { Musa sp. } \\
\text { [Musaceae] } \\
\text { Abolo kwon / AG517 }\end{array}$ & 4 & $\mathrm{CA}$ & Sh & G & $\mathrm{F}$ & $\begin{array}{l}\text { Peelings are sun dried \& burnt in the house } \\
\text { to produce smoke to repel mosquitoes. }\end{array}$ \\
\hline $\begin{array}{l}\text { Gossypium hirsutum L. } \\
\text { [Malvaceae] } \\
\text { Pama / AG516 }\end{array}$ & 3 & $\mathrm{CA}$ & Sh & G & $\mathrm{F}$ & $\begin{array}{l}\text { Cotton lint is sun dried \& burnt in the house } \\
\text { to produce smoke to repel mosquitoes. }\end{array}$ \\
\hline $\begin{array}{l}\text { Cleome gynandra L. } \\
\text { [Cleomaceae] } \\
\text { Akeyo / AG519 }\end{array}$ & 3 & $\mathrm{CA}$ & $\mathrm{H}$ & $H / G$ & L & $\begin{array}{l}\text { Leaves cooked with groundnut paste \& eat- } \\
\text { en as sauce for malaria prevention. }\end{array}$ \\
\hline $\begin{array}{l}\text { Hoslundia opposita Vahl } \\
\text { [Lamiaceae] } \\
\text { Itutu / AG511 }\end{array}$ & 2 & WA & $\mathrm{H}$ & $\mathrm{B} / \mathrm{G} / \mathrm{H}$ & L & $\begin{array}{l}\text { Squeeze handful of fresh leaves in water \& } \\
\text { use for bathing. }\end{array}$ \\
\hline $\begin{array}{l}\text { Solanum americanum Mill. } \\
\text { [Solanaceae] } \\
\text { Ocuga / AG518 }\end{array}$ & 2 & CA & $\mathrm{H}$ & $\mathrm{H} / \mathrm{G}$ & L & $\begin{array}{l}\text { Leaves cooked with groundnut paste } \& \text { eat- } \\
\text { en as sauce for malaria prevention. }\end{array}$ \\
\hline $\begin{array}{l}\text { Carica papaya L. } \\
\text { [Caricaceae] } \\
\text { Apapalo / AG512 }\end{array}$ & 1 & $\mathrm{CA}$ & $\mathrm{T}$ & $\mathrm{B} / \mathrm{G} / \mathrm{H}$ & L & $\begin{array}{l}\text { Mix with fresh leaves of Baccharoides } \\
\text { adoensis \& Tithonia diversifolia, boil \& drink. } \\
\text { Used in whole body steam baths as well. }\end{array}$ \\
\hline $\begin{array}{l}\text { Citrus sp. } \\
\text { [Rutaceae] } \\
\text { Cungwa / AG513 }\end{array}$ & 1 & $\mathrm{CA}$ & $\mathrm{T}$ & $\mathrm{G} / \mathrm{H}$ & $\mathrm{F}$ & $\begin{array}{l}\text { Cut } 4 \text { oranges } \& \text { mix with } 3 \text { cups }(\sim 30 \mathrm{ml}) \\
\text { of cool water. Drink } 3 \text { cups } 3 \text { times a day } \\
\text { for } 1 \text { day. }\end{array}$ \\
\hline $\begin{array}{l}\text { Pseudarthria hookeri Wight \& Arn. } \\
\text { [Fabaceae] } \\
\text { Abokecwari / AG } 514\end{array}$ & 1 & WR & Sh & $B / G$ & L & $\begin{array}{l}\text { Pound handful of fresh leaves } \& \text { mix with cool } \\
\text { water \& drink } 1 \text { tsp } 3 \text { times a day for } 4 \text { days. }\end{array}$ \\
\hline $\begin{array}{l}\text { Cucurbita maxima Duchesne } \\
\text { [Cucurbitaceae] } \\
\text { Acuca / AG520 }\end{array}$ & 1 & $\mathrm{CA}$ & Sc & $H / G$ & L & $\begin{array}{l}\text { Leaves cooked with groundnut paste \& eat- } \\
\text { en as sauce. }\end{array}$ \\
\hline
\end{tabular}




\section{Anywar et al. - Medicinal Plants Used in the Treatment and Prevention of Malaria in Cegere Sub-County, Northern Uganda}

12 were used exclusively for treatment of malaria, two species for both prevention and treatment, and eight exclusively for prevention. The most frequently used plant species for treating malaria was $S$. pinnata mentioned by 69 respondents $(77 \%)$. This was followed by Baccharoides adoensis (Sch.Bip. ex Walp.) H.Rob. (syn. Vernonia adoensis Sch.Bip. ex Walp.) (Asteraceae) mentioned by 31 respondents (34\%), then Azadirachta indica A. Juss. (Meliaceae) and Crotalaria sp. (Fabaceae) both mentioned by 18 respondents each $(20 \%)$. The plant families with the highest number of medicinal plant species for preventing and treating malaria were Asteraceae and Fabaceae with three plant species each. These were followed by Lamiaceae with two species. The rest of the plant families had only one plant species each.

Most of the medicinal plant species used for treating malaria were herbs (50\%), followed by trees $(25 \%)$, shrubs $(20 \%)$, and scramblers (5\%) (Table 2). Leaves (64\%) were the most frequently used parts for preventing and treating malaria. The least frequently used parts for preventing and treating malaria were the fruits and the rhizomes both at $4.5 \%$.

The most common method of preparation of the herbs for malaria treatment was decoction $(45 \%)$. These were prepared by boiling plant materials in a pot for 5 to 10 minutes and leaving them to cool before drinking. This was followed by cool water infusions $(20 \%)$, whereby the plant material was squeezed or crushed by hand, steeped in cool water, and drunk. Herbal baths were also prepared by squeezing the plant material in water and using the resultant mixture for bathing (20\%). The least common methods of preparation were chewing the fresh leaves $(10 \%)$ and steam baths (5\%). The most common method of preparation of the plant species for malaria prevention was by drying the plant material and burning it to produce smoke and also cooking the plant material and eating it as sauce, both at $38 \%$. The most common route of administration of the herbal medicines was oral $(71.4 \%)$ while the rest of the medicines were applied either topically (14.3\%) or inhaled (14.3\%).

Some of the medicines were used during the preparation of herbal or steam baths, e.g., Ocimum forsskaolii Benth. (Lamiaceae). Here, the plant material was boiled in water, and the patient was bathed in the medicine. Alternatively, the patients covered their heads over a basin containing the steaming herbal preparation and inhaled the steam. The majority of the plants were used as single remedies (e.g., Senna siamea (Lam.) H.S.Irwin \& Barneby (Fabaceae)) but are occasionally mixed with other herbs to boost their activity, particularly when treating resistant malaria (e.g., B. adoensis and Aloe vera (L.) Burm.f. (Xanthorrhoeaceae). Some plant parts, particularly the leaves, were reported to be chewed fresh and the juice swallowed for treatment, e.g., Moringa oleifera Lam. (Moringaceae).
The respondents preferred to make dried herbal preparations over fresh ones as these can be stored for a long time and are ideal when traveling, e.g., powder from $A$. indica.

\section{Plant collection areas}

Many of the plant species had multiple collection areas. For example, $S$. siamea could be harvested from either the bush or in people's gardens or around homesteads. Most (47.6\%) of the plant species used for preventing and treating malaria were both cultivated and abundant. On the other hand, $23.8 \%$ of the plant species were wild and abundant. Some of the plant species $(19.6 \%)$ were reported to be cultivated, but also occur in the wild and are considered rare. The rest were cultivated, grew in the wild, and were abundant. Although the most frequently mentioned plant species for treating malaria, Schkuhria pinnata, was cultivated and wild, it was considered rare by all the respondents interviewed because it was not possible to find any specimens in the wild. The only specimens seen and collected were from medicinal plant gardens of two traditional healers.

Most of the medicinal plant species for preventing and treating malaria were harvested from gardens and around the homesteads $(35 \%)$. These were followed by those plants that could be harvested from either the bush, gardens, and around people's homesteads (30\%). The least commonly used area for harvesting was by the roadside (5\%) where for example Tithonia diversifolia (Hemsl.) A.Gray (Asteraceae) was harvested. There was a general consensus among the traditional healers interviewed that the most ideal time for harvesting medicinal plants was between 10:30 am to 3:00 pm. During this time, the plant was believed to contain the highest amount of medicine while, during the night, the plants were believed to be "feeding." Generally, there were no serious restrictions placed on harvesting the medicinal plants.

\section{Knowledge transfer}

All respondents interviewed acknowledged that there were several ways through which the knowledge about medicinal plants and herbal treatments they had was acquired. These sources included their parents, grandparents, elders, friends, and relatives, but also through dreams. Such knowledge was passed on orally from one person to another. Three of the healers reported that they were taking records of the plants they use for future access and reference by their children. One traditional healer reported that he obtained his knowledge through dreams. The leader of the traditional healers reported that if a particular herbal remedy was found to be effective, its use was spread among the community members by word of mouth after being recommended by someone who used it and was cured. However, knowledge on malaria and its prevention and transmission was obtained through govern- 
ment programs and campaigns using local media such as radio stations, local leaders, and posters among others.

\section{Plants used in the prevention of malaria}

The respondents were aware that malaria could be prevented by sleeping under mosquito nets, destroying the breeding grounds of mosquitoes such as stagnant water and bushy areas, or using both natural and synthetic mosquito repellents (Table 2). They also reported that eating certain bitter herbs offered some protection against malaria. Because of the bitter taste of some of the herbs, they were often mixed with groundnut paste when preparing them to make their taste more palatable.

\section{Traditional prevention and treatment of malaria}

Some of the plant species used in malaria preventione.g., Crotalaria ochroleuca G.Don (Fabaceae) and Solanum americanum Mill. (syn. Solanum nigrum L.) (Solanaceae)-are both consumed as vegetables that help in malaria prophylaxis (Table 2). According to some of the elders (six) interviewed, the consumption of such plants is on the decline because of their bitter taste which many young people do not like. The traditional healers and TBAs interviewed reported that such herbs are purposefully eaten with the knowledge that they help in preventing malaria by boosting one's immunity. Other plant species are used as mosquito repellents such as $O$. forsskaolii and Manihot esculenta Crantz (Euphorbiaceae). These plants were usually dried and burned to produce smoke that repelled the mosquitoes.

All respondents did not report any side effects or contraindications on the use of S. pinnata. Most of the respondents reported S. pinnata to be their most effective medicinal plant for treating malaria. Its use differed slightly among the different users. While some preferred using it singly, others combined it with other herbs such as $A$. vera and $B$. adoensis.

The villages visited had numerous small drug shops that sold different anti-malarial drugs particularly quinine tablets and artemisinin based anti-malarials such as Coartem $^{\mathrm{TM}}$. These anti-malarial drugs were easily accessible when the need arose. Some of the herbalists, especially the experienced ones, were able to recognize the signs and symptoms of severe malaria and they would quickly refer patients to clinics once they were not responding to treatment. This happened when the patients were vomiting or were severely dehydrated. These quick referrals have been attributed to the sensitization the healers have received from different Non-Governmental Organizations (NGOs) and government programs but also because of fear of being arrested in case patients died at their premises. The healers generally believed that their medicine was effective and safer than the Western anti-malarial drugs because it did not produce the undesirable side effects commonly seen in some Western medicines.

\section{Discussion}

\section{The traditional concept of malaria}

The traditional conceptualization of malaria today by the Langi in Cegere Sub-County and healers in particular was found to be similar in many respects to Western medicine. This included the causes and symptoms. This can be attributed to influence and sensitization from Western culture introduced by the colonialists and still practiced today. The only notable difference was in attributing the cold air in the morning or evening to the spread of malaria, especially among children. With the coming of the colonialists, and formal education, the local name for malaria among the Langi, atipa, became less popular. The term "malaria" then became the more common way of referring to the disease. This explains why only five traditional healers and six elderly respondents were familiar with the name atipa.

The leader of the traditional healers also reported that he had observed some of the Arabs-who were at the time living in the Lango sub-region during the reign of the then president of Uganda (Idi Amin) in the 1970s-administering extracts of $S$. pinnata to their sick children. He then began experimenting with the plant and found it to be effective in treating malaria. The Arabs are known to have invaded the Acholi sub-region, which is adjacent to the Lango sub-region, where the current study area was found in the 1850s, around the time of the slave-ivory trade (Kustenbauder 2010). Schkuhria pinnata is popularly referred to as chloroquine apure, literally translating into the "chloroquine plant," because of its bitterness and perceived efficacy akin to chloroquine tablets. The genus Schkuhria comprises about 15 species and is distributed principally in the tropical areas of Central and South America (Ganzer \& Jakupovic 1990). Few Schkuhria species have been introduced into Africa (Ganzer \& Jakupovic 1990). This can explain why S. pinnata has no local name in Langi.

Schkuhria pinnata was regarded as the most potent anti-malarial plant by the majority of the respondents interviewed $(77 \%)$. Its use as an antimalarial has been reported in other ethnobotanical studies in Uganda by Adjanohoun et al. (1993) and Katuura et al. (2007), in Kenya by Kareru et al. (2006) and Njoroge et al. (2004), and in Zimbabwe by Gelfand et al. (1985).

Trotter and Logan (1986) observed that generally plants, which are used in repetitive fashion, are more likely to be biologically active. In this case, S. pinnata methanol and aqueous extracts have been shown to exhibit high antiplasmodial activity against chloroquine sensitive and re- 


\section{Anywar et al. - Medicinal Plants Used in the Treatment and Prevention of Malaria in Cegere Sub-County, Northern Uganda}

sistant Plasmodium falciparum (William H. Welch, 1897) clones in vitro with low cytotoxicity against human cells (Muthaura et al. 2007). Aqueous extracts of S. pinnata administered intra-peritoneally also suppressed growth of parasites in vivo in mice by $64 \%$, with no observed toxicity (Muthaura et al. 2007). On the contrary, a study by Deutschländer et al. (2009) showed that ethanol and acetone extracts of $S$. pinnata were cytotoxic at a concentration of $12.5 \mu \mathrm{g} / \mathrm{ml}$. However, it is important to remember that such extracts are different from the traditionally used aqueous preparations.

Schkuhria pinnata is widely used and believed to be efficacious. Preliminary information from literature suggests it is safe and bioactive, with low toxicity values $\left(\mathrm{LC}_{50}\right)$ below $1000 \mu \mathrm{g} / \mathrm{ml}$ (Bussmann et al. 2011, Muñoz et al. 2000). It is a good candidate for further investigation to verify its efficacy through a retrospective treatment outcome study.

Vernonia amygdalina Delile (Asteraceae), a close relative of $B$. adoensis, had the highest frequency of citation in Kibale in Southwestern Uganda (Namukobe et al. 2011). It has also been reported to be used for treating malaria in Ghana with a high frequency of citation (Asase et al. 2010). V. amygdalina has also been found to be moderately clinically effective in the treatment of malaria in adult patients (Challand \& Willcox 2009). B. adoensis and T. diversifolia have recently been reported to be among the most commonly used medicinal plants for treating malaria in Nyakayojo Sub-County in Western Uganda (Stangeland et al. 2011).

Some plant species were mentioned only once, an indicator that they are possibly not as popular as the others, due to several reasons, including perceived effectiveness, availability, lost or secret knowledge, and other medicinal uses among others. For example, Carica papaya L. (Caricaceae) which was only mentioned once is well known for having several medicinal and pharmacological properties including anthelmintic, antifungal, immunomodulatory and antimalarial activity, among others (Krishna et al. 2008). The leaves of $C$. papaya have also been reported to be used for treating malaria in Ghana and they were frequently cited by the respondent's interviewed (Asase et al. 2010). The same or related plant species have been recorded in different parts of Uganda and other African countries for treating malaria, for example $T$. diversifolia, $B$. adoensis, and $A$. indica, were reported by Stangeland et al. (2011) to be used for treating malaria in Western Uganda, while Ssegawa and Kasenene (2007) reported A. indica and Citrus limon (L.) Osbeck (Rutaceae) to be used in Southern Uganda for treating malaria.

Compared with other areas in Uganda, which have been surveyed for the use of medicinal plants in the treatment of malaria, a relatively smaller number of plants in Cegere Sub-County are used for treating malaria (12) despite the high incidence of the disease in the area. This is possibly because of the nature of the terrain in Cegere Sub-County and generally in the Apac District with about $5.4 \%$ of the total area being open water, and $4.8 \%$ being permanent or seasonal wetlands (UDIH, 2012). Only 12 medicinal plants are used specifically for treating malaria in Cegere Sub-County, compared to 20 medicinal plants in Kibale (Namukobe et al. 2011), 23 in the Sango bay area (Ssegawa \& Kasenene 2007), 48 in Nyakayojo, Mbarara District, Western Uganda (Stangeland et al. 2011), and 86 species in Mpigi District, central Uganda (Adia et al. 2014).

\section{Harvesting medicinal plants for treating malaria}

The leaves were reported to be the most frequently used plant parts for treating malaria. This was attributed to their potency and fast growth rate compared to other plant parts. Seasonality played a role in the harvesting and use of certain plant species in the treatment of malaria. For $A$. indica, although the whole plant could be used for treating malaria, the leaves were the most preferred part, especially during the rainy season when they were abundant and easiest to collect. During the dry season, other parts such as the bark could be used because the leaves are few. Whereas none of the informants considered time of day as an important factor in harvesting medicinal plant species in Ghana (Asase et al. 2011), it was an important consideration for traditional healers in Cegere Sub-County. Care was taken not to dry the harvested plant material in direct sunlight but rather in shade because they believed that the sun weakened the potency of the herbs. This is in agreement with scientific evidence because too much heat can decompose some organic compounds according to Trease and Evans (2009).

\section{Mode of preparation and administration}

Some of the herbs that were usually eaten as vegetables or sauce were prepared and administered differently for treatment of malaria (Table 2). For example the leaves of $C$. ochroleuca were cooked with groundnut paste and eaten as sauce but for malaria treatment; juice from the leaves was squeezed and drunk.

\section{Knowledge dynamics on medicinal plants for treating malaria}

The respondents acquired their knowledge through dreams, as well as from their parents, grandparents, and friends. The healers were actively involved in knowledge exchange through locally organized seminars. Some of the healers have undergone some basic training in primary health care, some by local NGOs. They have been trained to quickly assess the patients, make objective judgments, and refer seriously ill patients to health centers before it is too late. As a result of sensitization some of the herbalists were aware that fresh preparations would not last beyond four days without getting spoilt. To prolong the shelf life of the preparation, a little lemon juice 
was squeezed into the herbal preparation to function as a preservative.

\section{Conservation issues}

Some plant species were reported to be rare and some attempts were being made by some of the herbalists to propagate them around their homesteads. For example $S$. pinnata was found to be growing in medicinal plant gardens of two traditional healers. The categorization of the plant species in this study as either rare or abundant was based on the local people's ranking derived from their own experiences in locating any given plant species for use whenever need arose. This mainly depended on how easy it was to obtain a plant from the wild, compared to approximately 5 years ago or longer. For example, one had to walk long distances and spend a lot of time to find $S$. pinnata growing in the wild. Even when we came across some $S$. pinnata growing in the wild, its abundance and distribution was highly limited. This led the respondents to conclude that the plant was rare. None of the plant species documented in this study were listed on the IUCN's Red List of Threatened Species (www.iucn.redlist. org). Despite the fact that some plant species were beginning to be cultivated by some of the herbalists, they were considered to be rare. This can be attributed to the destructive methods of harvesting, when the whole plant is completely uprooted irrespective of its size, thus leaving no chance for the plant to grow and establish itself. This factor coupled with high demand contributed to scarcity of $S$. pinnata. Despite the fact that many of the medicinal plant species used were gathered from the wild, few efforts are being made to cultivate them because some people believed they grow abundantly in the wild.

\section{Conclusions}

There is widespread use of medicinal plants for treating malaria in Cegere because of the high incidence of malaria there. However, the number of plant species used is relatively lower than those reported in other areas of Uganda. Schkuhria pinnata was found to be the most widely used medicinal plant for treating malaria and could therefore be efficacious. The conceptualization of malaria by the Langi in Cegere Sub-County today is generally similar to the Western understanding of the disease. Local communities have their own conceptualizations of the disease which plays an important role in understanding how they respond to it in terms of prevention and treatment. Further research on the efficacy of $S$. pinnata in treating malaria should be conducted. The investigations should involve ascertaining the safety, efficacy, chemical constituents, and possible mode of action of the species. The conservation of some key plants especially those considered to be effective and rare such as $S$. pinnata should be encouraged. Future research should also be undertaken in policy formulation regarding the incorporation of ITM in the treatment of malaria at a national level.

\section{Authors' Contributions}

GA, CK, and PAN participated in the designing of the protocol for the survey. GA, PR, and RB participated in carrying out the survey. PR did the identification of all the plant species. All the authors participated in writing and giving feedback on the manuscript. All authors have read and approved the final manuscript.

\section{Acknowledgments}

We are grateful to the authorities of Apac District and Cegere Sub-County for allowing us to conduct this research. We also grateful to Mr. Ongu Patrick, CDO, Cegere SubCounty, who introduced to us to the traditional herbalists and all other respondents we interviewed, and assisted in language interpretation. Our sincere thanks also go to the traditional herbalists and other respondents for agreeing to participate in this study and not forgetting Mr. Okello Tom and Mr. Odyeny Robby. This work is part of the Multi-disciplinary University Traditional Health Initiative (MUTHI) project, which receives financial support from EU-FP7-AFRICA-2010, grant number 266005.

\section{Literature Cited}

Adia, M.M., G. Anywar, R. Byamukama, M. Kamatenesi-Mugisha, Y. Sekagya, E.K. Kakudidi \& B.T. Kiremire. 2014. Medicinal plants used in malaria treatment by Prometra herbalists in Uganda. Journal of Ethnopharmacology 155:580-588. dx.doi.org/10.1016/j.jep.2014.05.060

Adjanohoun, J.E., M.R.A. Ahnyi, A.L Aké, A.M Alia, C.A Amai, Z. Gbile, C.L.A. Johnson, Z.O. Kakooko, H.K. Lutankome, O. Morakinyo, N.K. Mubiru, J.W. Ogwal-Okeng \& E.A. Sofowora. 1993. Contribution to Ethnobotanical and Floristic Studies in Uganda. Organization of African Unity/Scientific Technical \& Research Commission (OAU/ STRC), Lagos, Nigeria.

Asase, A., G.A. Akweteya \& D.G. Achel. 2010. Ethnopharmacological use of herbal remedies for the treatment of malaria in the Dangme West District of Ghana. Journal of Ethnopharmacology 129:367-376. dx.doi.org/10.1016/j. jep.2010.04.001

Batista, R., A. de. Jesus Silva Junior \& A.B. de Oliveira. 2009. Plant-derived antimalarial agents: New leads and efficient phytomedicines. Part II. Non-alkaloidal natural products. Molecules 14(8):3037-3072. dx.doi. org/10.3390/molecules 14083037

Bloland, P.B., M. Ettling \& S. Meek. 2000. Combination therapy for malaria in Africa: Hype or hope. Bulletin of 


\section{Anywar et al. - Medicinal Plants Used in the Treatment and Prevention of Malaria in Cegere Sub-County, Northern Uganda}

the World Health Organization 78(12):1378-1388. http:// www.who.int/bulletin/archives/78\%2812\%291378.pdf

Bussmann, W.R., G. Malca, A. Glenn, D. Sharon, B. Nilsen, B. Parris, D. Dubose, D. Ruiz, J. Saleda, M. Martinez, L. Carillo, K. Walker, A. Kuhlman \& A. Townesmith. 2011. Toxicity of medicinal plants used in traditional medicine in Northern Peru. Journal of Ethnopharmacology 137(1):121-140. dx.doi.org/10.1016/j.jep.2011.04.071

Challand, S. \& M. Willcox. 2009. A clinical trial of the traditional medicine Vernonia amygdalina in the treatment of uncomplicated malaria. Journal of Alternative and Complementary Medicine 15(11):1231-1237. dx.doi. org/10.1089/acm.2009.0098

Deutschländer, M.S., M. van de Venter, S. Roux, J. Louw \& N. Lall. 2009. Hypoglycaemic activity of four plant extracts traditionally used in South Africa for diabetes. Journal of Ethnopharmacology 124:619-624. dx.doi.org/10.1016/j. jep.2009.04.052

Diallo, D., A. Maiga, C. Diakite \& M. Willcox. 2004. Malarial-5: Development of an antimalarial phytomedicine in Mali. Pp. 134-150 in Traditional Medicinal Plants and Malaria. Edited by M. Willcox, G. Bodeker \& P. Rasoanaivo. CRC Press, London, U.K.

Frosch, A.E.P., M. Venkatesan \& M.K. Laufer. 2011. Patterns of chloroquine use and resistance in sub-Saharan Africa: A systematic review of household survey and molecular data. Malaria Journal 10:116. dx.doi. org/10.1186/1475-2875-10-116

Ganzer, U. \& J. Jakupovic. 1990. Schkuhripinnatolides, unusual sesquiterpene lactones from Schkuhria pinnata. Phytochemistry 29(2):535-539. dx.doi.org/10.1016/00319422(90)85113-T

Gelfand, M., R.B. Drummond, S. Mavi \& B. Ndemera. 1985. The Traditional Medical Practitioner in Zimbabwe: His principles of practice and pharmacopoeia. Mambo Press, Gweru, Zimbabwe.

Heckathorn, D.D. 2011. Comment: Snowball versus respondent-driven sampling. Sociological Methodology 41(1):355-366. dx.doi.org/10.1111/j.1467$\underline{9531.2011 .01244 . x}$

Kamya, M.R., N.N. Bakyaita, A.O.Talisuna, W.M. Were \& S.G. Staedke. 2002. Increasing antimalarial drug resistance in Uganda and revision of the national drug policy. Tropical Medicine and International Health 7(12):10311041. dx.doi.org/10.1046/j.1365-3156.2002.00974.x
Kareru, P.G., G.M. Kenji, A.N. Gachanja, J.M. Keriko \& G. Mungai. 2006. Traditional medicines among the Embu and Mbeere peoples of Kenya. African Journal of Traditional, Complementary and Alternative Medicines 4(1):75-86. dx.doi.org/10.4314/ajtcam.v4i1.31193

Katuura, E., P. Waako, J.R.S.Tabuti, R. Bukenya-Ziraba \& J. Ogwal-Okeng. 2007. Antiplasmodial activity of extracts of selected plants used by local communities in Western Uganda for treatment of malaria. African Journal of Ecology 45(S3):94-98. dx.doi.org/10.1111/j.13652028.2007.00864.x

Kiwanuka, S.N., E.K. Ekirapa, S. Peterson, O. Okui, M.H. Rahman, D. Peters \& G.W. Pariyo. 2008. Access to and utilisation of health services for the poor in Uganda: A systematic review of available evidence. Transactions of the Royal Society of Tropical Medicine and Hygiene 102:1067-1074. dx.doi.org/10.1016/j.trstmh.2008.04.023

Krishna, K.L., M. Paridhavi \& J.A. Patel. 2008. Review on nutritional, medicinal and pharmacological properties of papaya (Carica papaya Linn.). Natural Product Radiance 7(4):364-373.

Kuglerova, M., H. Tesarova, J.T. Grade, K. Halamova, O. Wanyana-Maganyi, P. van Damme \& L. Kokoska. 2011. Antimicrobial and antioxidative effects of Ugandan medicinal barks. African Journal of Biotechnology 10(18):36283632.

Kustenbauder, M. 2010. Northern Uganda: Protracted conflict and structures of violence. Pp 451-482 in War and Peace in Africa. Edited by T. Falola \& R.C. Njoku. Carolina Academic Press, Durham, North Carolina, U.S.A.

Martin, G.J. 1995. Ethnobotany: A methods manual. Chapman \& Hall, London, U.K.

MoH (Ministry of Health). 2006. Uganda Malaria Control Strategic Plan (UMCSP) 2005/06 - 2009/10. Malaria Control Programme, Kampala, Uganda.

MoH (Ministry of Health). 2010. Uganda Malaria Control Strategic Plan (UMCSP) 2010/11-2014/15. Malaria Control Programme, Kampala, Uganda.

Muñoz, V., M. Sauvain, G. Bourdy, S. Arrázola, J. Callapa, G. Ruiz, J. Choque \& E. Deharo. 2000. A search for natural bioactive compounds in Bolivia through a multidisciplinary approach: Part III. Evaluation of the antimalarial activity of plants used by Alteños Indians. Journal of Ethnopharmacology 71(1-2):123-131. dx.doi.org/10.1016/ $\underline{\text { S0378-8741(99)00191-9 }}$

Muthaura, C.N., G.M. Rukunga, S.C. Chhabra, S.A. Omar, A.N. Guantai, J.W. Gathirwa, F.M. Tolo, P.G. Mwitari, L.K. Keter, P.G. Kirira, C.W. Kimani, G.M. Mungai \& E.N.M. 
Njagi. 2007. Antimalaria activity of some plants traditionally used in Meru district of Kenya. Phytotherapy Research 21:860-867. dx.doi.org/10.1002/ptr.2170

Namukobe, J., J.M. Kasenene, B.T. Kiremire, R. Byamukama, M. Kamatenesi-Mugisha, S. Krief, V. Dumontet \& J.D. Kabasa. 2011. Traditional plants used for medicinal purposes by local communities around the northern sector of Kibale National Park, Uganda. Journal of Ethnopharmacology 136:236-245. ‥dx.doi.org/10.1016/j. jep.2011.04.044

NGIA (National Geospatial-Intelligence Agency). 2015. Geographical Names Database. www.geographic.org/ geographic names/name.php?uni=9050298\&fid=6449\&c =uganda. Accessed 03 August 2015.

Njoroge, N.G., W.R. Bussmann, B. Gemmill, L.E. Newton \& V.W. Ngumi. 2004. Utilisation of weed species as sources of traditional medicines in Central Kenya. Lyonia 7(2):7287. http://lyonia.org/viewArticle.php?articleID=314

Okigbo, R.N., C.L. Anuagasil \& J.E. Amadi. 2009. Advances in selected medicinal and aromatic plants indigenous to Africa. Journal of Medicinal Plants Research 3(2):127134.

Okello, P.E., W. van Bortel, A.M. Byaruhanga, A. Correwyn, P. Roelants, A. Talisuna, U. d'Alessandro \& M. Coosemans. 2006. Variation in malaria transmission intensity in seven sites throughout Uganda. American Journal of Tropical Medicine Hygiene 75(2):219-225.

Ssegawa, P. \& J.M. Kasenene. 2007. Plants for malaria treatment in Southern Uganda: Traditional use, preference and ecological viability. Journal of Ethnobiology 27:110 131. dx.doi.org/10.2993/0278-0771(2007)27[110:PFMTI S]2.0.CO;2

Stangeland, T., P.E. Alele, E. Katuura \& K.A. Lye. 2011. Plants used to treat malaria in Nyakayojo sub-county, Western Uganda. Journal of Ethnopharmacology 137:154-166. dx.doi.org/10.1016/j.jep.2011.05.002
UBOS (Uganda Bureau of Statistics). 2010. Statistical Abstract. Statistics house, Kampala, Uganda.

UDIH (Uganda Districts Information Handbook). 2012. Uganda Districts Information Handbook. Expanded edition. Fountain Publishers, Kampala, Uganda.

Tabuti, J.R.S. 2008. Herbal medicines used in the treatment of malaria in Budiope county, Uganda. Journal of Ethnopharmacology 116:33-42. dx.doi.org/10.1016/j. jep.2007.10.036

Trease, E.C.W. \& D. Evans. 2009. Pharmacognosy. 15th edition. Elsevier Ltd, London, U.K.

Trotter, R.T. \& H.M. Logan. 1986. Informant consensus: A new approach for identifying potentially effective medicinal plants. Pp. 91-112 in Plants Used in Indigenous Medicine and Diet: Biocultural approaches. Edited by N.L. Etkin. Redgrave Publishing Company, Bedford Hills, New York, U.S.A.

Willcox, M., G. Burford \& G. Bodeker. 2004. An overview of ethno-botanical studies on plants used for the treatment of malaria. Pp. 187-197 in Traditional Medicinal Plants and Malaria. Edited by M. Willcox, G. Bodeker \& P. Rasoanaivo. CRC Press, Boca Raton, Florida, U.S.A.

Willcox, M., F. Benoit-Vical, D. Fowler, G. Bourdy, G. Burford, S. Giani, R. Graziose, P. Houghton, M. Randrianarivelojosia \& P. Rasoanaivo. 2011. Do ethnobotanical and laboratory data predict clinical safety and efficacy of antimalarial plants? Malaria Journal 10(Suppl 1):S7. dx.doi. org/10.1186/1475-2875-10-S1-S7

WHO. 2008. World Malaria Report 2008. World Health Organization, Geneva, Switzerland. www.who.int/malaria/ publications/atoz/9789241563697/en/. Accessed 1 October 2014 .

WHO. 2013. World Malaria Report 2013. World Health Organization, Geneva, Switzerland. www.who.int/malaria/ publications/world malaria_report_2013/en/. Accessed 1 October 2014. 